\title{
TRENDS IN DEVELOPMENT OF AIRCRAFT FOR REGIONAL ROUTES: IMPACT ON THE EUROPEAN AIR TRANSPORTATION SYSTEM
}

\author{
Allan Nõmmik ${ }^{1,2}$ \\ ${ }^{1}$ Estonian Aviation Academy, \\ Lennu 40, Reola, Kambja Parish, \\ Tartu County 61707, Estonia \\ allan.nommik@eava.ee \\ ${ }^{2}$ School of Engineering: Department of Mechanical and Industrial Engineering: Research Centre of \\ Logistics and Transportation, Tallinn University of Technology, \\ Ehitajate 5, Tallinn, 19086, Estonia
}

Keywords: Regional aircraft, air transportation system, Public Service Obligations

\begin{abstract}
The beginning of the twenty-first century in air transportation is characterized by increasing competition between (regular, i.e. not low-cost) airlines, which in its turn affects the low cost airlines by necessitating for them the operating of aircraft with larger seat capacity also on local routes, with the goal of operating the aircraft at lower cost per available seat kilometer. Taking into account the importance of air connections for the regional economy, the local authorities are obligated to support regional airports and impose public service obligations on some routes. This study examines the regional aircraft development after the air transportation market liberalization, while also delving into the background of differences in environments of operation in Europe and United States. To evaluate the regional routes' equipment competitiveness, this research is focusing on to the regional aircraft fuel consumption which is the considerable factor for airline's operating costs. Analysis of the differences between operating environments in Europe and the United States is based on an earlier review of the research findings on development of the markets after liberalization, and the role regional aircraft in air transportation system. Also, the comparisons of the profitability and airlines' strategies in both regions are given. The results provide insights into the main drivers of regional aircraft design and development from the demand's point of view.
\end{abstract}

\section{INTRODUCTION}

One of the identified, key priorities of Aviation Strategy for Europe [20] focuses on "tackling limits to growth in the air and on the ground, by reducing capacity constraints and improving efficiency and connectivity". Its content is coherently linked with that of the other one; "improving services, market access and investment opportunities with third countries, whilst guaranteeing a level playing field" [20]. Factually, the steady growth in air transport has not affected all important airports in Europe.

Infrastructure of regional airports could be seen as an access gateway to the surrounding region for people mobility, for social equity and economic growth. At the same time, some smaller ones, e.g. nonhub airports or often also called regional or peripheral airports, will either lose their air traffic or get in a hurry of developing it for themselves. If there is no operator willing to provide scheduled services on 
some air route which is vital for regional development, "under the conditions imposed, the government may restrict a single carrier's access to the route financial compensation to the carrier in compliance with the Public Service Obligations (hereafter PSO)". [4]. This trend affects not only the EU outlying regions, but also Central European airports. For example, in 2017, two airports in Czech Republic were seeking potential carriers, with the help of PSO tenders. The Ostrava airport wanted to find an airline which could operate the air routes to Amsterdam and Helsinki; while the Brno airport was looking for airline to operate the route to Munich [21]. Several research articles have their focus on PSO effectiveness, $[1,4,15,16]$. In some cases, it is also understandable as this applies to hard-toreach locations, such as small islands. At the same time, there is noticeable interest for supporting international routes also under the rules of the PSO.

The need to identify of the causes leading to the decrease of the number of regional aircraft in Europe, led to the two-fold goal to be reached in this paper: first, to assess the competitiveness of regional aircraft; and second, to examine conditions in US-EU the air transportation markets.

\section{OVERVIEW OF MARKETS FOR REGIONAL AIRCRAFT}

In the 21th century the world's air transportation system connects thousands of airports. Theoretically, each air route has its own demand characteristics, which is subject to changes over time. Firstly, each air route's demand cannot be standard in size. Secondly, each air route's demand cannot be constant and by considering the factors such as seasonality of demand, all extraordinary events, etc. have the impact on demand volatility over time. Sometimes these fluctuations of demand can be totally or partly flattened by revenue management tools if the demand has enough elasticity for price and is flexible in time. It means that at different times for every route one may require an aircraft with different dimensionality determined by the number of seats $n,(1 \leq n \leq x)$. For obvious reasons, flights from smaller airports with a modest potential of catchment area could require equipment with suitable capacity or smaller size aircraft.

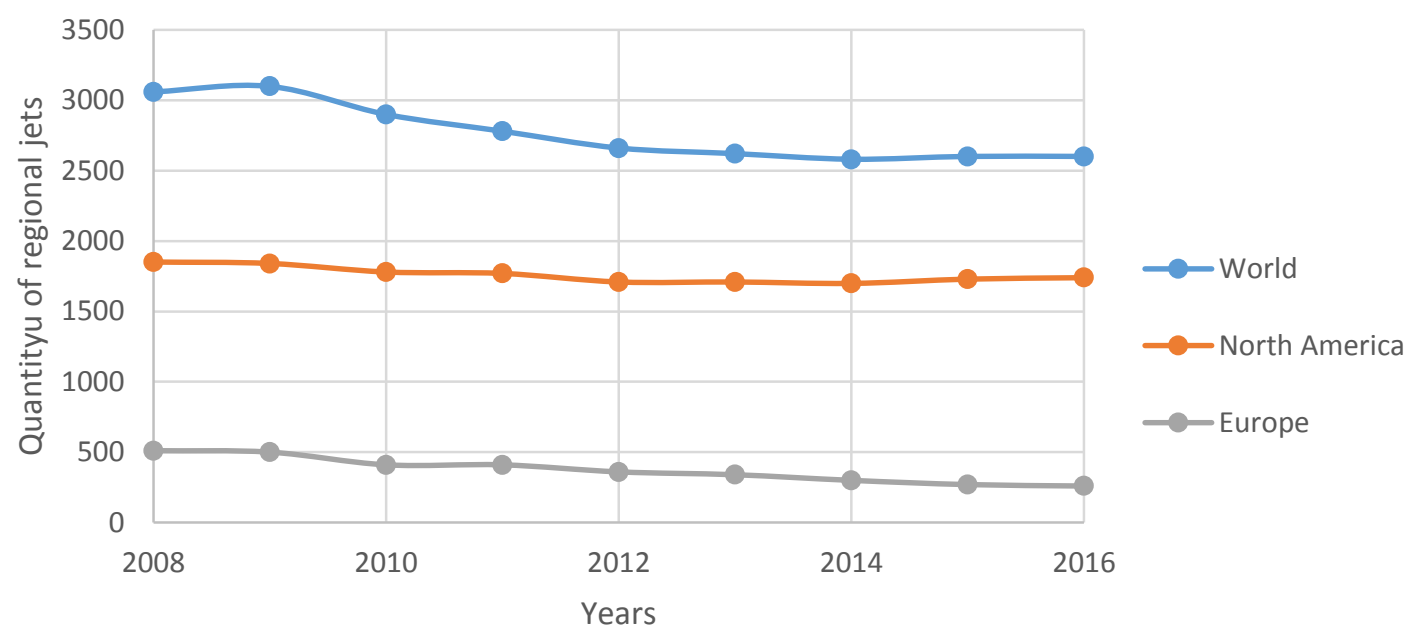

Figure 1. Regional jet aircraft quantity changes 2008-2016 in Europe and North America. Source: [19].

This paper focuses on aircraft size which is determined by number of seats $n$ less than $100(n<100)$. The sample derives from the availability of statistical data from the given aircraft segment and from the fact that the difference in the capacity of these aircraft from mainline narrow body aircraft families (such as Boeing 737NG/737 MAX and Airbus A320/A320Neo) is about twofold or more. In terms of passengers' capacity, the latter fact makes it possible to distinguish this aircraft market's segment from widely used and popular narrow body aircraft. For testing of regional jet (hereafter RJ) aircraft with 
$n<100$ quantity changes in the world during 2008-2016, data has been collected from the Boeing CURRENT MARKET OUTLOOKS (from 2009 to 2017). Figure 1. shows RJ quantity changes in the world and accordingly in Europe and North America. In this market segment more than half of this size aircraft operated on the North America market alone. Although the number of regional jet aircraft in North America remained unchanged, their number in Europe was diminished by a half during the 8 years.

The circumstances that come to light in Figure 1 can be linked with the liberalization of the US air transport market which started in 1978 as one of the most important milestones determining today's air transport. One of the impacts given by the liberalization of air transportation market in the US, is the strengthening of the hub and spoke system which is measured according as the airport concentration enables the growing of one airline's market share in hub airports [9]. This was achieved by increasing the frequencies and number of destinations to provide better connection opportunities. [12] For many routes, it was complemented by the introduction of smaller aircraft. [7] Main carriers recognized the using of regional airlines' services at less profitable markets or in circumstances where the regional airlines had cost advantages [8]. Smaller aircraft, in comparison with larger ones, had lower operating costs, especially when the for regional flights specialized airline operator was a different one, often independent of the main carrier. Today these airlines in US market operate under long term outsourcing agreements [12] for one or more main carriers. [8] Savings are generated by regional airlines using various staffing principles, including salaries. Provisions in US major airlines' pilot contracts that impose limits called "scope clause" on the operation of aircraft, are used by regional airlines. Under the scope clause, the summarized restrictions are $[7,13]$ :

1. number of seats in the aircraft, generally 76 seats or less;

2. aircraft Maximum Take Off Weights (MTOW), 86,000 lb (39 t) or less;

3. ratio of regional jets to mainline jets operating for the airline.

As a result of the ongoing transformation of the US air transport network, it became necessary to operate aircraft at larger distances, which required faster airplanes [3]. This time coincided with the low oil price period at the end of the last century [23]. The number of flights served by RJ increased several times, from 74 routes in 1996 to 1091 routes in 2005 [3].

European air transportation liberalization was a step-by-step process. [2, 11]. "The 'Third Package' of European Union air transport liberalization measures took effect on 1 January 1993 and has substantially reduced the restrictions on interstate flight operations. The EU commuter carrier sector is clearly at an earlier stage of development." [11]. Comparing the liberalization processes in EU with that in the US one can find that "the EU liberalization package does not address the role and potential of smaller air carriers in the single market and accordingly does not attempt to redefine the role of air transport in linking smaller centres in the much larger European Union". [11] In Europe, one must also take into account the fact that in the European Union there was an air transport system in which the Member States had their own national airlines, whose activities also supported separate bilateral agreements with third countries. Mainly, flag carries or subsidiaries have also been operators of RJ and turboprop aircraft, which in turn has prevented the creation of different working conditions for smaller aircraft personnel.

The earlier market liberalization in the US contributed to the emergence of nationwide air carriers operating in the single economic space where all airlines can see the whole US market like a home market. It has been found that "use of larger aircraft with lower flight frequency may constitute a better strategy in a slot-constrained European environment". [6] This claim can be understood as 
highlighting the cost-effectiveness of large aircraft. Additionally, the bigger long haul aircraft using maximum high density seat configuration will be more fuel effective on shorter routes compared to the smaller ones [10].

However, the analysis [8] of regional air fares in different countries has revealed that in North America the regional fares are considerably higher than those in Australia, New Zealand, Norway and Sweden. The authors have observed the regional airlines as a strategic tool implemented by the network companies to compete against "less efficient airlines" and found that cooperation is based, in particular, on servicing business destinations, since leisure destinations have higher price elasticity. It has also been found that at markets it is the size that has impact on this cooperation: at small markets "cost advantage of the regional airlines is more significant". [8] Here, however, it can be understood that under the cost-effectiveness the authors have kept in mind the total cost of the aircraft operation.

It has been recognized that there are three windows of opportunity for the development of regional aircraft: market's demand, available technology and regulatory system. [14] The regulatory system for regional aircraft can be linked to the scope clauses and environmental regulations; the demand such as developing of US and EU markets, changes of oil prices, passenger preferences; the technological competitive advantages related primarily to new engines, but also to other innovative solutions such as development and use of new materials [14].

\section{FUEL EFFICIENCY OF REGIONAL AIRCRAFT}

Fuel consumption remains an important parameter for determining the competitiveness of the aircraft. The share of fuel cost may vary in the aircraft total operating costs. It depends on several factors, including fuel price, aircraft ownership costs, maintenance costs, flight crew costs, etc.

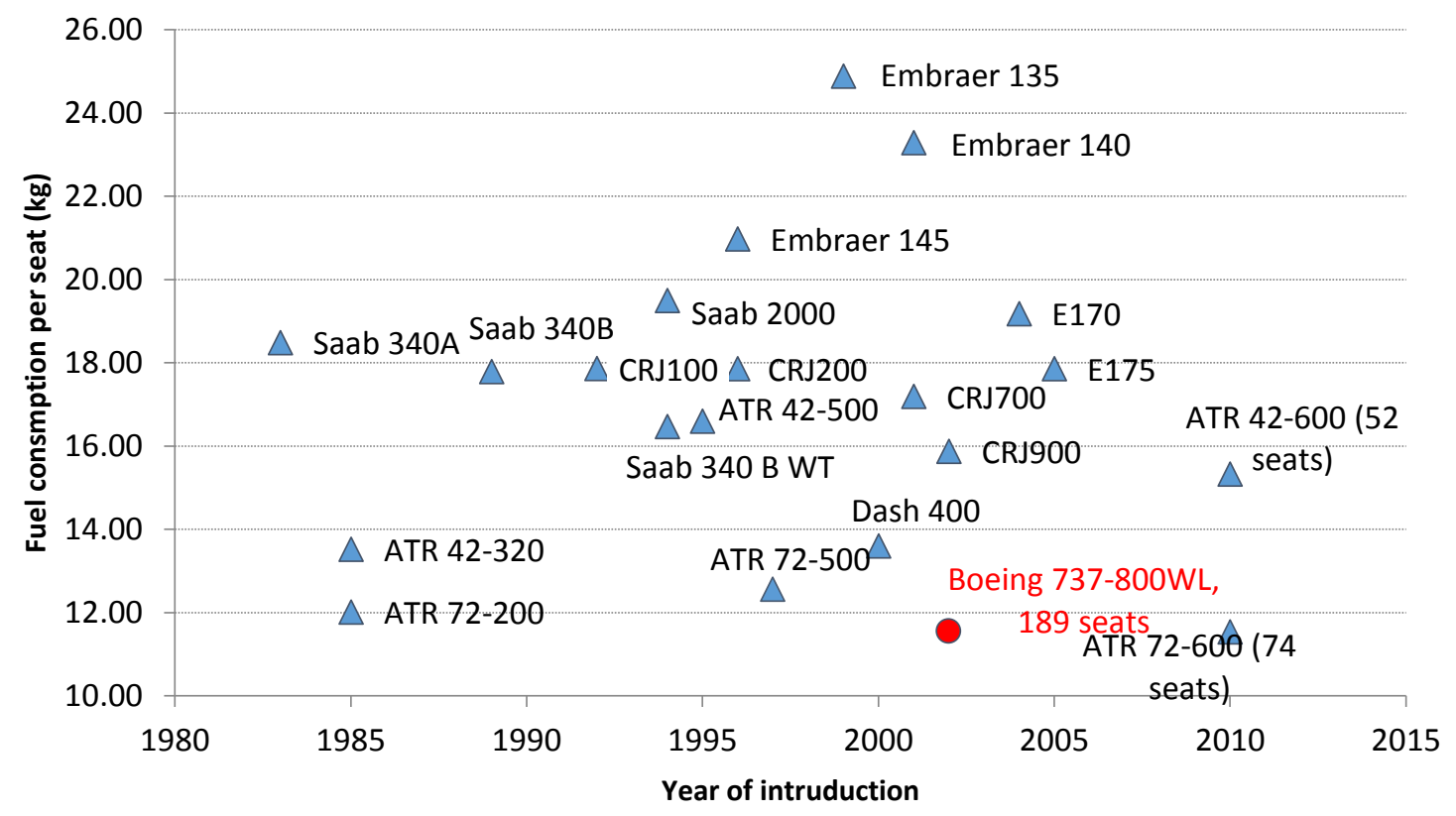

Figure 2. Fuel consumption per seat at the $300 \mathrm{~nm}$ route.

Figure 2 shows the regional aircraft, turboprop and RJ $(33 \leq n<100)$ fuel consumption per seat when operating at $300 \mathrm{~nm}$ route. The data were collected from articles published in Aircraft Commerce journal and open resources of aircraft manufactures [17-18, 25]. If the sources had left the fuel consumption data at close to $300 \mathrm{~nm}$ undisclosed, the results were obtained by interpolation. For comparison, the data of the mainline aircraft Boeing 737-800 ( $n=189)$ with winglets have been 
provided to serve as an example of common equipment of low cost airlines. The author has found, that despite the general tendency to reduce fuel consumption in air transport, the regional lines of the aircraft industry are not strongly in line with this trend. Only ATR 72-600 on shorter routes while, extremely rarely, using high density sitting layout can compete with a Boeing 737-800 winglets equipped configuration having 189 seats.

\section{COMPARING THE US AND EUROPEAN AIR TRANSPORTATION MARKETS}

Earlier studies on EU-US air transportation markets often focused on cost-effectiveness $[7,8,10]$. Profitability data of the US and EU airlines are given in Figure 3. It can be inferred that airline companies stably earn higher profits per passenger in the US market.

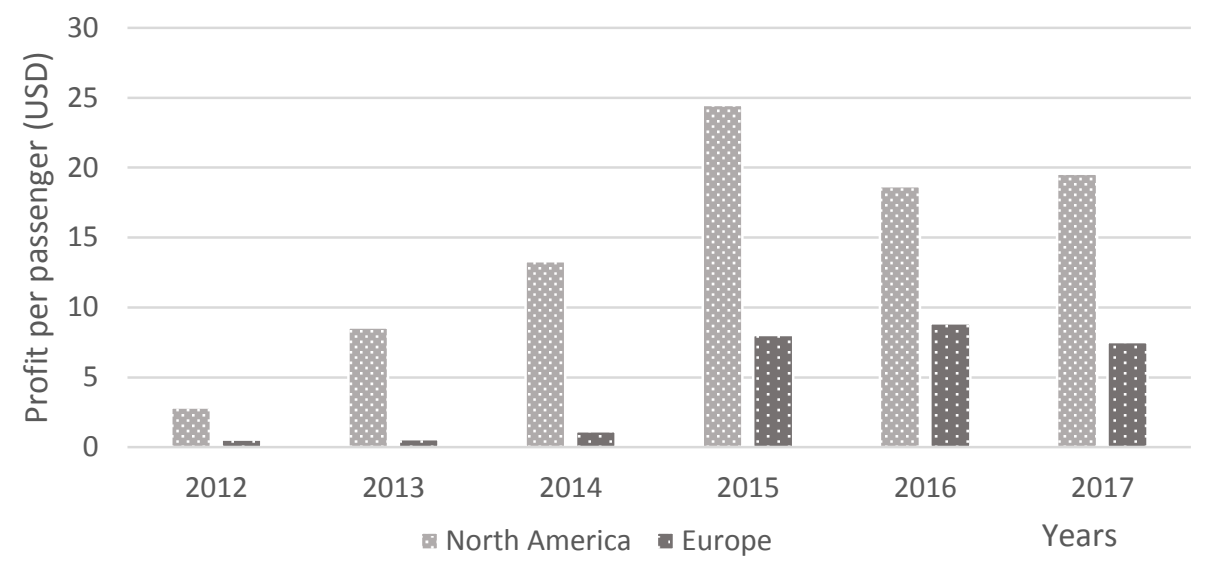

Figure 3. US and European airlines' profit per one air passenger. Source: [22]

To explain the factors affecting profits of US airlines, a comparison of the US and EU airlines has been made (see Table 1), to find out the revenues earned per passenger kilometer by airline companies. United Airlines data is provided both, in consolidated and also separately per each mainline and regional unit.

\begin{tabular}{|c|c|c|c|c|}
\hline Airline & $\begin{array}{l}\text { Passengers } \\
\text { (thousands) }\end{array}$ & $\begin{array}{l}\text { Passenger } \\
\text { kilometers } \\
\text { (millions) }\end{array}$ & $\begin{array}{l}\text { Average passenger } \\
\text { distance, total }(\mathrm{km})\end{array}$ & $\begin{array}{l}\text { Yield in Euro } \\
\text { cents (per RPK) }\end{array}$ \\
\hline $\begin{array}{l}\text { United Airlines consolidated } \\
\text { (mainline and regional) }\end{array}$ & 35,152 & 81,622 & 2322 & 8,53 \\
\hline United mainline & 24,169 & 71,567 & 2961 & 7,61 \\
\hline United regional & 10,983 & 10,005 & 911 & 13,87 \\
\hline KLM & 28,562 & 93,228 & 3264 & 7,40 \\
\hline SAS* & 26,941 & 30,561 & 1134 & 9,36 \\
\hline
\end{tabular}

Table 1. Operation results of selected European air carries and United Airlines in 2015. Source: United Airlines Announces Full-Year 2015 Profit; KLM. 2015 Annual Report; SAS Annual Report 2014/2015. *- SAS operational year NOVEMBER 2014OCTOBER 2015

As a rule, European carriers do not provide separate statistics on their regional units. In order to gain a more objective picture, two airlines KLM and SAS were selected in Europe. The passenger turnovers of both airlines are close to those of United Airlines. KLM has its own regional airline KLM Cityhopper. SAS is operating many regional routes in and across Scandinavia. Owing to its geographical location many flights have their destinations across the Baltic Sea, which reduces the competitiveness of other modes of transport. The currency exchange rates were obtained from European Central Bank (ECB) 
database. From the comparison shown in the Table 2, it appears that if at mainline the US and EU longer routes are almost equal, then on the regional routes, the US market indicator significantly exceeds the European one.

\section{DISCUSSION}

For bringing out the role of regional aircraft in US air transportation system, there were four motives of using RJ in the US air transportation market: reduction of capacity, frequency supplement, opening of new services and replacement of turboprop aircraft on the longer routes [7]. The lack of these aircraft may interfere with the performance of these functions in the European air transportation system. Two examples of constraints due to the lack of RJ in Europe have been collected from airlines' websites and shown in Table 2.

\begin{tabular}{llllll}
\hline Route & Airline & $\begin{array}{l}\text { Great circle } \\
\text { distance }(\mathrm{km})\end{array}$ & Aircraft & Seats $(\mathrm{n})$ & $\begin{array}{l}\text { Scheduled } \\
\text { block time }\end{array}$ \\
\hline $\begin{array}{l}\text { Prague (PRG) - } \\
\text { Bucharest (OTP) }\end{array}$ & ČSA & 1084 & A319 & $\begin{array}{l}140 / 142 / 144 \\
1 \mathrm{~h} 55 \mathrm{~m}\end{array}$ \\
$\begin{array}{l}\text { Helsinki (HEL) - } \\
\text { Gdansk (GDN) }\end{array}$ & Finnair & 768 & ATR72-500 & $58 / 60 / 64$ & $2 \mathrm{~h} \mathrm{45m}$ \\
\hline
\end{tabular}

Table 2. Examples of constraints due to the lack of RJ in Europe

The first example is related to airlines' flexibility in following the demand. The Czech national airline ČSA has no RJ aircraft in its fleet and it uses the fuel consumption effective aircraft ATR 72-500 (see Figure 2) for regional routes. This aircraft type is also sometimes used for the Prague - Bucharest route due to the demand characteristics and competition situation requiring smaller size aircraft. It is evident that due to the difference in block time, it is not possible to operate turboprop and mainline narrow body aircraft under the same flight plan (see Table 2). Secondly, thanks to the speed advantages, RJ airplanes could handle more flights per day on such long lines. The same ČSA behavior has been found at other air routes which could be suitable for RJ from Prague in 2018, e.g. Stockholm and Kiev.

The second example is related to the strengthening of the hub and spoke network in Helsinki Airport. Finnair is the national carrier of Finland which is focusing on connecting of European airports with destinations in Asia. In 2018 this airline had no RJ aircraft with $n<100$ in its own fleet. Consequently, this limits the ranges of the airline to operate possible routes between Central European regional airports and its own hub airport. Considering the operation efficiency, the longest route with Finnair code of ATR 72-500s aircraft is Helsinki-Gdansk (see Table 2).

Developing of technology, for example, within the framework of the European Clean Sky 2 program, is an important consideration while developing appropriate engines for regional aircraft, which would ensure the competitiveness of RJ compared to larger aircraft. By using allegations such as [14] model of windows of opportunity for development of regional aircraft and taking into account the results obtained, one can allege that the major demand as well as accompanying regulations in the form of scope clause, are directly related to the US market as the largest market of this segment aircraft. It can be argued that nowadays RJ aircraft design and production decisions are based on the circumstances of the US market, which, on the one hand, limits both the seats number and MTOW that impedes the application of new technologies. For example, the new but heavier engine for RJ aircraft, PW1200G/1700G is coming from PW1000G family, which was designed primarily for bigger, mainline aircraft, yet and alongside it has also been developed for RJ aircraft. With the reduction of bypass ratio 
from 12.5 or 12 to 9 for propelling the RJ the smaller engine turned out to be less effective in terms of noise insulation, emissions and fuel consumption than the bigger and more powerful models of the engine's family. [24] Additionally, the launch of the aforementioned engine-powered RJ aircraft will also be delayed due to its failure to fit into the preset scope clause' weight parameters. [13]

Looking at the market size of RJ aircraft, it can be alleged that new technologies can remain unused or their application delayed if the relevant market does not conform to the given aircraft. In order to find differences between US and EU air transport operating conditions, it is also appropriate to look at the competing modes of transport. From the viewpoint of vehicle speed, the high speed train is the biggest competitor to air transport. The analysis [5] "presented the trends in RJ aviation market and focused on main manufacturers: Bombardier of Canada and Embraer of Brazil" argue, that "Europe has different uses for RJs operation due to the extensive network of trains, which can be used on shorter trips". Actually, high speed railway network in EU is much larger that in US. Europe has $9.298 \mathrm{~km}$ of high speed rail vs $735 \mathrm{~km}$ in the US. [26]

It should also be taken into account that the availability of the regional aircraft in Europe is also limited. Therefore, in order to encourage airline companies to operate airplanes of the same size and using US experience of cooperation between mainline and regional carrier, contracts for the provision of PSO could be based on long-term agreements. Here, it should be taken into account that the PSO's compensation rate depends on the efficiency of the aircraft operation.

\section{CONCLUSIONS}

This study enabled to recognize regional airports' difficulties that emanate from shortage of regional aircraft in Europe. Despite the growth of air transportation, it turned out that in 2008-2016 the number of RJ aircraft with less than 100 seats decreased in Europe almost by half. At the same time, it has been found that the number of these airplanes, during the period under study in North America, did not make major changes and accounted for more than half of the RJ fleet globally. According to this study, there is reason to assert that the development of regional aircraft is based on North American operating conditions.

In the part of evaluation of competitiveness of RJ aircraft, these analyses focused primarily on the fuel consumption of aircraft, which has a clear impact on operating costs of the regional aircraft, as well as on emissions. The latter fact deserves more and deeper consideration. Here, fuel consumption has been used as a parameter to demonstrate technological development as a fact per se. Analysis of regional and mainline aircraft development showed that the fuel efficiency of the respective engines developed is more modest than that of regional aircraft, which is sufficient for the US market but does not fully satisfy European airlines. Comparison of the operation environments in EU and US shows higher profitability of airlines in US, which is partly based on the passengers' higher willingness to pay on regional routes in the US market. The study also revealed that in Europe there is high competition between high speed rail and air transportation. It was found that in order to design competitive aircraft for regional routes, it is also important to create conditions that may lead to an established market. The airlines' consolidation and long-term PSO agreements could be a prerequisite for development of the market for RJ or same size future analogs in Europe.

From the academic perspective, the diverse market research is very important for developing the new projects, such as those related to regional aircraft, in order to ensure future success. 


\section{REFERENCES}

[1] Abreua, J., Fagedab, X., Jiménezc J. L. (2018). An empirical evaluation of changes in Public Service Obligations in Spain. Journal of Air Transport Management, 67, 1-10.

[2] Button, K. (2001). Deregulation and Liberalization of European Air Transport Markets. Innovation, 14 (3), 255-275.

[3] Brueckner, J. K., Pai, V. (2009). Technological innovation in the airline industry: The impact of regional jets. International Journal of Industrial Organization, 27, 110-120.

[4] Bråthen, S., Eriksen, K.S. (2018). Regional aviation and the PSO system - Level of Service and social efficiency. In: Journal of Air Transport Management, 69, 248-256.

[5] Curtis, T., Rhoades, D. L., \& Waguespack, B. P. (2013). Regional Jet Aircraft Competitiveness: Challenges and Opportunities. World Review of Entrepreneurship, Management and Sustainable Development, 9(3). 1-13.

[6] Fageda, X., Flores-Fillol, R. (2012). Air services on thin routes: regional versus low-cost airlines, Reg. Sci. Urban Econ., 42 (4). 702-714.

[7] Forbes, S., Lederman, M. (2007). The role of regional airlines in the U.S. Airline, Industry. Lee, Darin (Ed.), In: Advances in Airline Economics, Vol. II. Elsevier.

[8] Gillen, D., Hazledine, Tim. (2015). The economics and geography of regional airline services in six countries, Journal of Transport Geography, 46, 129-136.

[9] Goetz, A.R., Sutton, C.J. (1997) The Geography of Deregulation in the U.S. Airline Industry. Annals of the Association of American Geographers, 87(2), 238-263.

[10] Park, Y., O'Kelly, M. E. (2014). Fuel burn rates of commercial passenger aircraft: variations by seat configuration and stage distance. Journal of Transport Geography, 41, 137-147.

[11] Reynolds-Feighan, A.J. (1995). European Air Transport Public Service Obligations: A Periodic Review Press. Fiscal Studies, 16, 58-74.

[12] Reynolds-Feighan, A.J. (2018). US feeder airlines: Industry structure, networks and performance. Transportation Research Part A: Policy and Practice, Volume 117. 142-157.

[13] Russell, E. (2018). ANALYSIS: Are US airlines at their next scope crossroads? Flight Dashboard.

[14] Vértesy, D. (2017). Preconditions, windows of opportunity and innovation strategies: Successive leadership changes in the regional jet industry, Research Policy, Volume 46, Issue 2. 388-403.

[15] Williams, G. (2010). European experience of public service obligations. In: Bråthen, S., Williams, G. (Eds.), Air Transport Provision in Remoter Regions. Ashgate Publishing.

[16] Wittman, M. D., Allroggen, F., Malina, R. 2016. Public service obligations for air transport in the United States and Europe: Connectivity effects and value for money. In: Transportation Research, Part A, 94, 112-128.

[17] Aircraft Commerce. (2007-2010). AIRCRAFT OPERATOR'S \& OWNER'S GUIDE: ATR 42/72; CRJ FAMILY; Dash 8 \& Q Series; E-JET FAMILY; ERJ-135/-140/-145; 737NG FAMILY. In: [http://www.aircraft-commerce.com/]

[18] ATR. (2014). ATR -600 SERIES. In: [www.atraircraft.com/] 
[19] Boeing. (2009-2017). CURRENT MARKET OUTLOOK: 2009-2028; 2010-2029; 2011-2030; 20122031; 2013 - 2032; 2014-2033; 2015-2034; 2016-2035; 2017-2036. (9 reports).

[20] European Commission. (2015). An Aviation Strategy for Europe. [In: https://ec.europa.eu/]

[21] European Commission. Public Service Obligations (PSOs). In: [https://ec.europa.eu/transport/modes/air/internal-market/pso_en]

[22] IATA. (2013-2018). ECONOMIC PERFORMANCE OF THE AIRLINE INDUSTRY (7 reports). In: [https://www.iata.org/publications/economics/Pages/index.aspx]

[23] IATA. (2018). Fact Sheet Fuel. In: [https://www.iata.org/]

[24] MTU Aero Engines. (2017). PurePower PW1000G Engine. In: [https://www.mtu.de/engines/]

[25] Saab AB. (2009). Product info. Saab 340A EASA, Saab 340B EASA, Saab 340 PLUS EASA, Saab 2000 EASA. In: [http://www.saabaircraftleasing.com/]

[26] UIC Passenger Department. (2018). High Speed lines in the World. In: [https://uic.org/]

\section{COPYRIGHT STATEMENT}

The authors confirm that they, and/or their company or organization, hold copyright on all of the original material included in this paper. The authors also confirm that they have obtained permission, from the copyright holder of any third party material included in this paper, to publish it as part of their paper. The authors confirm that they give permission, or have obtained permission from the copyright holder of this paper, for the publication and distribution of this paper as part of the READ 2018 proceedings.

This is an open access article distributed under the Creative Commons Attribution License which permits unrestricted use, distribution, and reproduction in any medium, provided the original work is properly cited. (CC BY 4.0). 